\title{
Gene expression profile analysis of Manila clam (Ruditapes philippinarum) hemocytes after a Vibrio alginolyticus challenge using an immune-enriched oligo-microarray
}

Rebeca Moreira ${ }^{1}$, Massimo Milan², Pablo Balseiro ${ }^{1}$, Alejandro Romero ${ }^{1}$, Massimiliano Babbucci², Antonio Figueras ${ }^{1}$, Luca Bargelloni $^{2}$ and Beatriz Novoa ${ }^{1 *}$

\begin{abstract}
Background: The Manila clam (Ruditapes philippinarum) is a cultured bivalve with worldwide commercial importance, and diseases cause high economic losses. For this reason, interest in the immune genes in this species has recently increased. The present work describes the construction of the first $R$. philippinarum microarray containing immune-related hemocyte sequences and its application to study the gene transcription profiles of hemocytes from clams infected with $V$. alginolyticus through a time course.

Results: The complete set of sequences from $R$. philippinarum available in the public databases and the hemocyte sequences enriched in immune transcripts were assembled successfully. A total of 12,156 annotated sequences were used to construct the $8 \times 15$ k oligo-microarray. The microarray experiments yielded a total of 579 differentially expressed transcripts. Using the gene expression results, the associated Gene Ontology terms and the enrichment analysis, we found different response mechanisms throughout the experiment. Genes related to signaling, transcription and apoptosis, such as IL-17D, NF-KB or calmodulin, were typically expressed as early as 3 hours post-challenge (hpc), while characteristic immune genes, such as PGRPs, FREPs and defense proteins appeared later at $8 \mathrm{hpc}$. This immune-triggering response could have affected a high number of processes that seemed to be activated $24 \mathrm{hpc}$ to overcome the Vibrio challenge, including the expression of many cytoskeleton molecules, which is indicative of the active movement of hemocytes. In fact functional studies showed an increment in apoptosis, necrosis or cell migration after the infection. Finally, $72 \mathrm{hpc}$, activity returned to normal levels, and more than $50 \%$ of the genes were downregulated in a negative feedback of all of the previously active processes.

Conclusions: Using a new version of the R. philippinarum oligo-microarray, a putative timing for the response against a Vibrio infection was established. The key point to overcome the challenge seemed to be 8 hours after the challenge, when we detected immune functions that could lead to the destruction of the pathogen and the activation of a wide variety of processes related to homeostasis and defense. These results highlight the importance of a fast response in bivalves and the effectiveness of their innate immune system.
\end{abstract}

Keywords: Ruditapes philippinarum, Vibrio alginolyticus, Hemocytes, Oligo-microarray, Gene ontology, Blast2GO, Immune response

\footnotetext{
* Correspondence: beatriznovoa@iim.csic.es

${ }^{1}$ Instituto de Investigaciones Marinas (IIM), Consejo Superior de

Investigaciones Científicas (CSIC), Eduardo Cabello 6, 36208 Vigo, Spain

Full list of author information is available at the end of the article
} 


\section{Background}

The Manila clam (Ruditapes philippinarum) is a cultured bivalve species with high worldwide commercial importance and value. The culture of these clams has been increasing in recent years, especially in Europe and Asia. Therefore, diseases can result in significant economic losses. The majority of diseases in clams are associated with Vibrio [1,2] and Perkinsus [3,4] species. Diseases can affect not only the development and survivorship of these organisms $[5,6]$ but also the quality and price of the product. Therefore, there has been a growing interest in the study of the molecular biology of the defense mechanisms in bivalves in the last decade. Although molluscs lack a specific immune system, the innate response involving circulating hemocytes and a large variety of molecular effectors seems to be an efficient defense method for responding to external aggressions by detecting the molecular signatures of an infection [7-11]. Hemocytes are the main line of cellular defense against invading pathogens in molluscs [12], and the immune genes expressed in bivalve hemocytes are of great interest to researchers [13-19]. In recent years, a serious effort has also been made to increase the number of $R$. philippinarum sequences in public databases. Before 2011, less than 6,000 nucleotide sequences were available for this species. Our two groups released 457,717 and 975,190 raw reads from adult/larval tissues and hemocytes, respectively [20,21]. Concurrently, studies by Ghiselli et al. on gonad tissue yielded approximately 90 million raw sequences [22].

Oligo-microarrays are a sensitive and reproducible highthroughput technology for analyzing the gene expression of thousands of genes simultaneously [23]. This platform has been used by scientists to study the expression profile in many species from yeast to human [24,25]. Microarrays have also been applied to bivalves for different purposes [26-28]. To our knowledge, a toxicogenomics study in the gill and the digestive gland [20] and a recent study of the response to brown ring disease, [29] are the only works to date to use an oligo-microarray in $R$. philippinarum.

The main objective of this work was to analyze the response of the Manila clam against strain TA15 of $V$. alginolyticus through a time course. $V$. alginolyticus was previously reported to produce important mortality in clam larvae [6]. For this study, a new version of Manila clam DNA microarray including the sequences of thousands of hemocyte-exclusive genes [21] was designed and developed.

\section{Results and discussion}

\section{Assembly and annotation}

A summary of the sequence origin, assembly and annotation results is shown in Table 1 . From the total 1,438,665 sequences from $R$. philippinarum, the Newbler software package (GS De Novo Assembler v2.6, Roche) was able to
Table 1 Description of the microarray design process

$\mathrm{n}^{\circ}$ sequences

\begin{tabular}{|c|c|}
\hline \multicolumn{2}{|l|}{ Sequence origin } \\
\hline Sanger (Milan et al. [20]) & 5,758 \\
\hline 454 tissues (Milan et al. [20]) & 457,717 \\
\hline 454 hemocytes (Moreira et al. [21]) & 975,190 \\
\hline sUbTOTAL & $1,438,665$ \\
\hline $\mathrm{NCBI}$ & 2,050 \\
\hline TOTAL & $1,440,715$ \\
\hline \multicolumn{2}{|l|}{ Assembly } \\
\hline Singletons & 169,223 \\
\hline Singletons phred Q > 20 & 16,495 \\
\hline Isotigs & 26,708 \\
\hline Isogroups & 15,175 \\
\hline Contigs & 156 \\
\hline \multicolumn{2}{|l|}{ Annotation } \\
\hline Singletons phred Q > 20 and NCBI & 5,914 \\
\hline Contigs and longest isotig of each isogroup & 6,242 \\
\hline Frame + & 7,827 \\
\hline Frame - & 2,761 \\
\hline Ambiguous frame & 1,568 \\
\hline TOTAL R. philippinarum successfully designed probes & 13,671 \\
\hline
\end{tabular}

assemble $88.24 \%$ of the raw sequences, and $11.76 \%$ of the sequences $(169,223)$ remained as singletons. The assembly resulted in 26,708 isotigs grouped into 15,175 isogroups and 156 contigs.

The longest isotig of each isogroup, the contigs, the singletons with more than $200 \mathrm{bp}$ of continuous sequence with a Phred $\mathrm{Q}>20(16,495)$ and the $R$. philippinarum ESTs in the NCBI database $(2,050)$ were then considered for the annotation. The putative identities of these sequences were obtained by running BlastX and BlastN similarity searches in 48 different protein and nucleotide databases. Additional file 1: Table S1 shows the percentage value of annotation success of each database. The protein databases showed a higher average percentage of matches (18.84\%) than the nucleotide ones (5.3\%), presumably due to the degeneration of the genetic code. Furthermore, the species databases yielded much lesser annotation percentage than the general ones (NCBI) with the exception of certain databases, probably because of the huge amount of sequences available, in the case of $H$. sapiens, or the higher phylogenetic similarity, with S. purpuratus and L. gigantea. Thus, we found it is worth the use of general protein databases and the specific ones previously named since only $1.5 \%$ of the contigs/isotigs and the $4.1 \%$ of the singletons were annotated with the remaining specific databases. A total of 12,156 successfully annotated transcripts were considered for the $R$. philippinarum DNA 
microarray design (see Methods). As most sequence reads were obtained from a non-directional cDNA library, sense strand orientation was inferred putatively from the homologous protein sequences of other species. One probe for annotated transcripts with known orientation was designed to construct a high-density oligo-DNA microarray, while two probes with both orientations were designed for contigs with ambiguous orientation (see Table 1). A total of 13,671 probes representing 12,108 unique transcripts were created using the Agilent eArray interface (https:// earray.chem.agilent.com/earray/).

\section{Microarray hybridization, robustness and validation}

A total of 36 microarray experiments were performed. The upper and lower fluorescence values were erased from the raw data $\left(20-90^{\text {th }}\right.$ percentile) in all of the experiments, and only robust fluorescence values were used to analyze the expression and function of the results.

Quantitative PCR (qPCR) is commonly used to confirm the results obtained from microarray analysis, and although microarray and qPCR data could disagree, it is known that qPCR using SYBR Green is useful to validate Agilent inkjet-printed 60-mer oligo-microarrays [30]. Specific primers were designed to perform a qPCR for four selected genes with cDNAs synthesized from the same RNAs used for the microarray hybridization. The expression patterns identified for these genes by the array and by qPCR showed similar profiles (Figure 1).
Significant differences in expression compared with the controls (t-test, $\mathrm{p}<0.05$ ) were observed in the qPCR results and matched the microarray results in most of the cases (IL-17D $3 \mathrm{~h}$, LTBP-4 $8 \mathrm{~h}$ and $24 \mathrm{~h}$ ) but showed some new significant results in one case (IL-17D $72 \mathrm{~h}$ ). The direction of the regulation was always comparable in both techniques.

The four genes selected for qPCR were chosen based on their relevance in the immune system. The complement component C3 is the central component of the complement system, whose functions are to distinguish and eliminate pathogens and trigger an inflammatory response [31]. The complement system has been characterized in the carpet shell clam $R$. decussatus and was found to be inhibited early after a Vibrio challenge, which concurs with our results [32]. The interleukin (IL) 17D belongs to a particular family with no sequence similarity to any other known cytokines. In humans, IL-17D regulates cytokine production in endothelial cells and has an inhibitory effect on hematopoiesis [33]. Previous works in vertebrates and invertebrates have analyzed IL-17 expression after a bacterial challenge [34,35]. These studies showed a general increase in IL-17 expression until a maximum level was reached between 6 and 24 hours post-challenge in both vertebrates and invertebrates, with the exception of the turbot intestine. In this fish species, the expression profile of IL-17 is more similar to our results, with an initial increase and subsequent

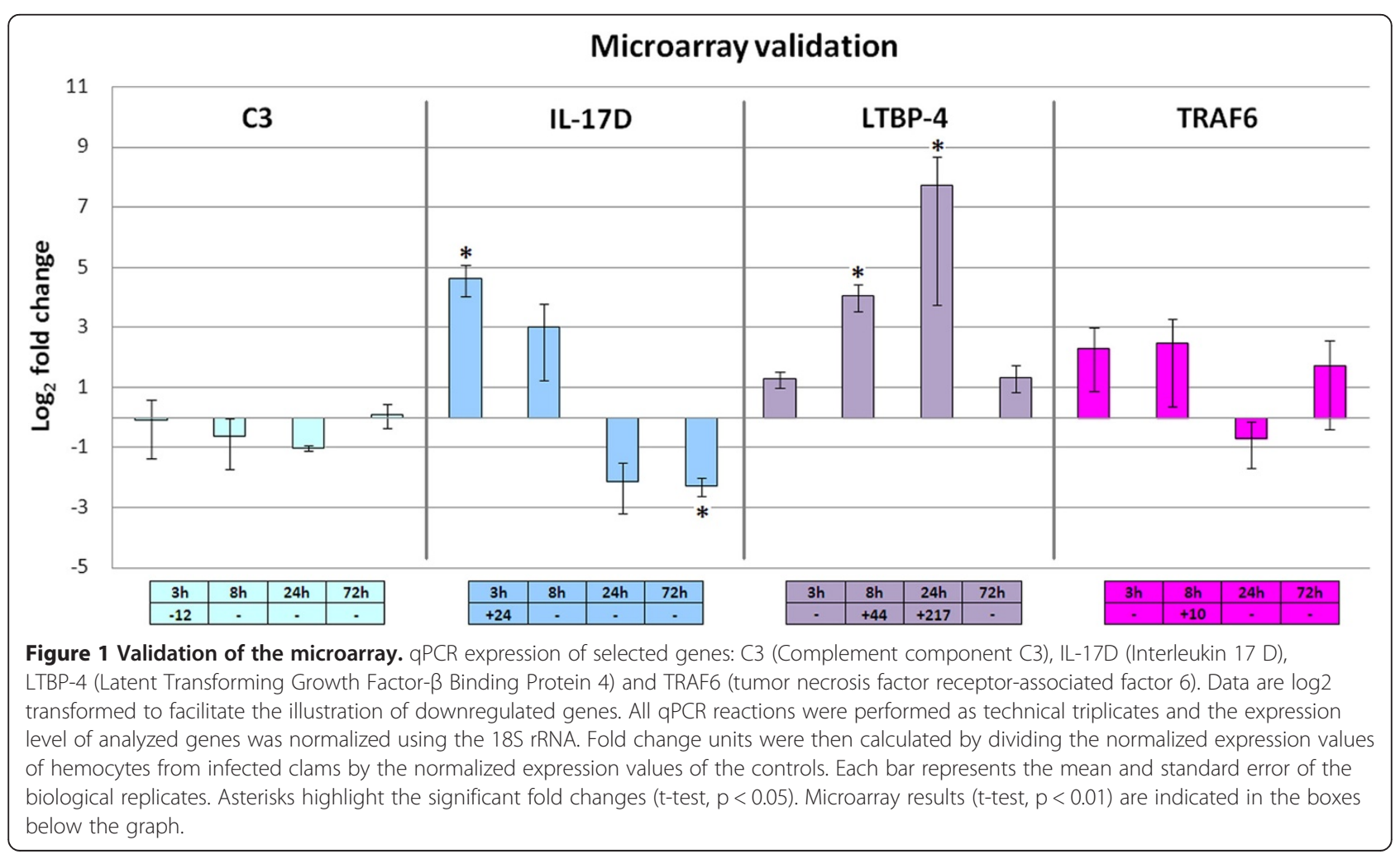


decrease and inhibition. The latent-transforming growth factor beta-binding protein 4 (LTBP-4) assists in TGF- $\beta$ folding, secretion and activation by mediating its matrix targeting [36] and is also involved in cell adhesion and migration [37]. The TNF receptor-associated factor 6 (TRAF6) is a key signaling adaptor molecule common to the TNFR superfamily and the IL-1R/TLR family that leads to the activation of the nuclear factor kappa-B $(\mathrm{NF}-\mathrm{kB})$ and AP-1 transcription factors. TRAF6 has been identified in other bivalves, such as the Zhikong scallop [38], and the expression of TRAF6 in hemocytes after a bacterial challenge (peptidoglycan) in vitro indicates an initial significant inhibition of TRAF6 transcription $(3 \mathrm{~h})$ followed by a subsequent recovery of the basal levels $(6 \mathrm{~h})$. This result does not coincide with our results in either expression or in timing, and this discrepancy could be a result of the different experimental designs. Nevertheless a late inhibition (24 h) and recuperation of the basal expression $(72 \mathrm{~h}$ ) was observed in $R$. philippinarum.

\section{Gene expression profile after TA15 stimulation}

To select genes that were significantly regulated by the $V$. alginolyticus challenge, we performed a t-test $(\mathrm{p}<0.01)$ to find genes that were significantly different between the control and infected samples and an ANOVA $(\mathrm{p}<0.05)$ to analyze the effect of the challenge in the whole dataset.

The t-test yielded the identification of 579 differentially expressed genes between the control groups and the Vibrio-infected groups. The highest number of differentially expressed genes (209) was found 8 hours after the challenge, while 125, 152 and 93 significantly differentially expressed genes were found 3, 24 and 72 hours after challenge, respectively. The expression pattern is an increase in the number of differentially expressed genes to 8 hours and a progressive decrease until reaching the minimum at 72 hours after the challenge. Figure 2 summarizes the results of the t-test and describes the number of regulated genes in fold change groups.

A Venn diagram illustrates the expression of the exclusive and common genes between the different sampling times in response to $V$. alginolyticus (Figure 3). This Venn diagram shows that the general transcription pattern of these genes is on/off, which implies that the majority of the genes were regulated at a single point (on) and only transcribed at basal levels the rest of the time (off). The genes expressed at several time points were scarce (21 out of $579,3.63 \%$ ), and only the ras-related c3 botulinum toxin substrate 3 (RAC3), a small GTPase of the Rho family implicated in cell differentiation, migration and apoptosis [39], was expressed in three consecutive sampling points (3, 8 and 24 hours post-challenge). In Figure 3, the coincident genes detected by the ANOVA and the t-test are also shown. The ANOVA analysis resulted in 15 regulated genes, and interestingly, 13 of these genes were in the group of 8 hours post-challenge and 8 genes were exclusive to this sampling point (for a description of these genes, see the ANOVA section).

The sequences of the regulated genes in each sampling time ( $\mathrm{t}$-test, $\mathrm{p}<0.01$ ) were analyzed in a Gene Ontology (GO) approach to cluster them into groups depending on the biological process in which the genes were involved and the time of maximum expression (Figure 4). Moreover, Table 2 shows the top 25 expressed genes in each sampling point. With this information, it is possible to infer the timing of the $R$. philippinarum response to a $V$. alginolyticus challenge. We have to take into account that the cumulative mortality rate at the end of the experiment, 72 hours, was $44 \%$. The high mortality assures an infection but at the same time it is not too high allowing the clams to be able to fight against Vibrio.

In the first sampling point, 3 hours post-challenge, the results of the GO term analysis (Figure 4A) showed that most of the genes that were differentially expressed belonged to the cellular process category that involves many different functions. More specifically, one of the principal processes with a maximum expression at this sampling point was related to cellular component organization and biogenesis, leading to the assembly, disassembly or arrangement of the constituent macromolecules of the cell. Signaling and death processes were also present to trigger the response to the pathogen and eliminate compromised cells after an infection. Following the same line, the main functions of the top 25 hemocyte genes in the first sampling time were in accordance with the GO results. The most significantly upregulated gene $3 \mathrm{hpc}$ (Table 2) is related to the cytoskeleton (dynein light chain) and could be involved in cellular spreading, chemotaxis and adhesion (RAC3, perlucin-like protein). However, the signaling and transcription processes (LTBP-4, phosphoinositide 3-kinase adapter protein 1, adp-ribosyl cyclase, HMG box transcription factor Sox17) could lead to a rapid triggering of several mechanisms, including the calcium-dependent processes that can lead to apoptosis via calmodulin activation [40]. Another upregulated gene was prothrombin, which is related to coagulation, but strikingly, there was an absence of the inflammatory response at the transcription level, as demonstrated by the strong inhibition of the complement factor C3.

In Figure 4B, 8 hours after challenge, the most represented functions are those related to response to stimulus and immune system. These processes initiate the response to the pathogen after the initial triggering of the signaling pathways. The GO term multi-organism process, with genes such as TRAF6, is also closely related because an interaction between clams and $V$. alginolyticus is implied. These results coincide with the information obtained in the top-list where genes involved in defense and wound 


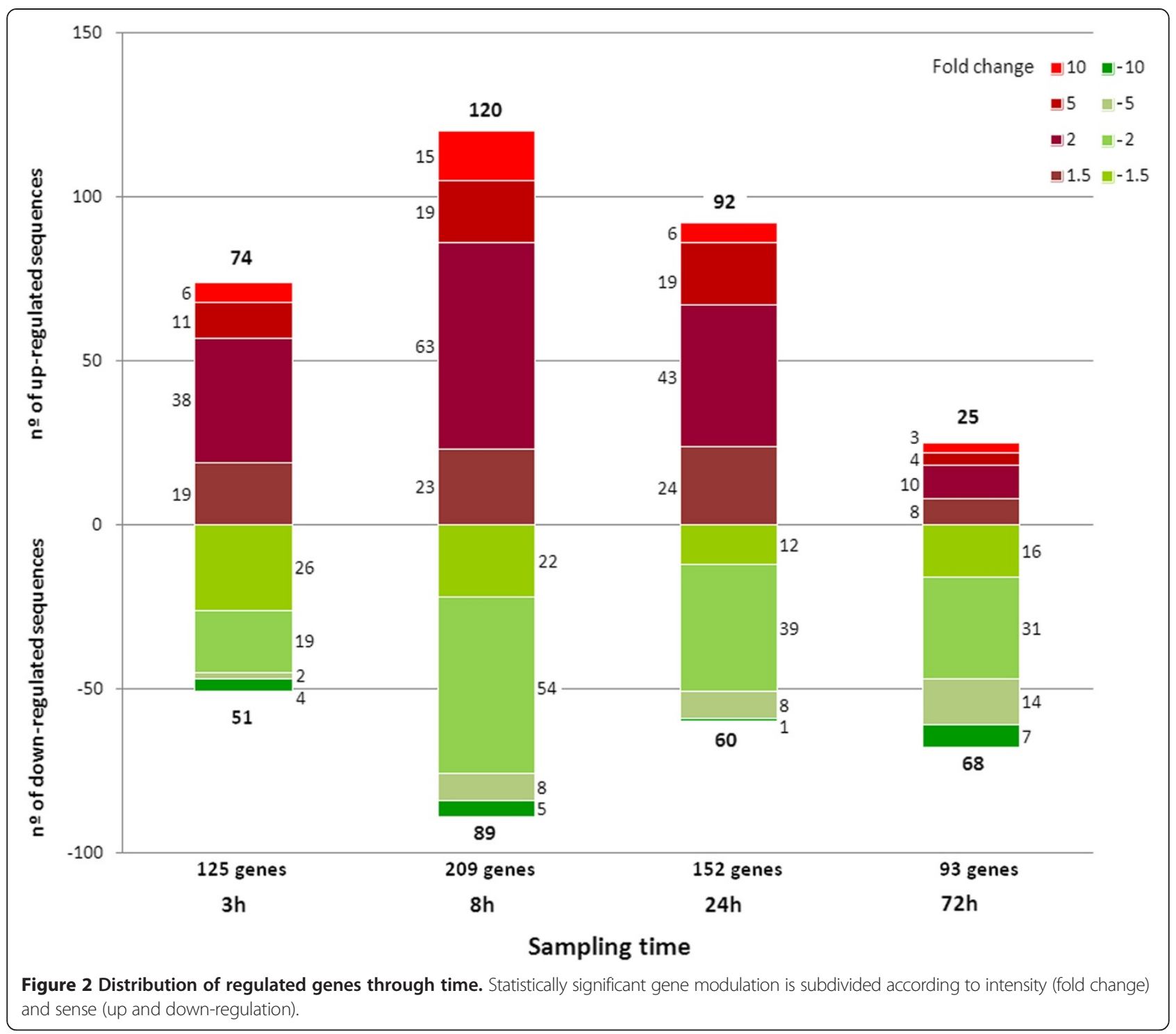

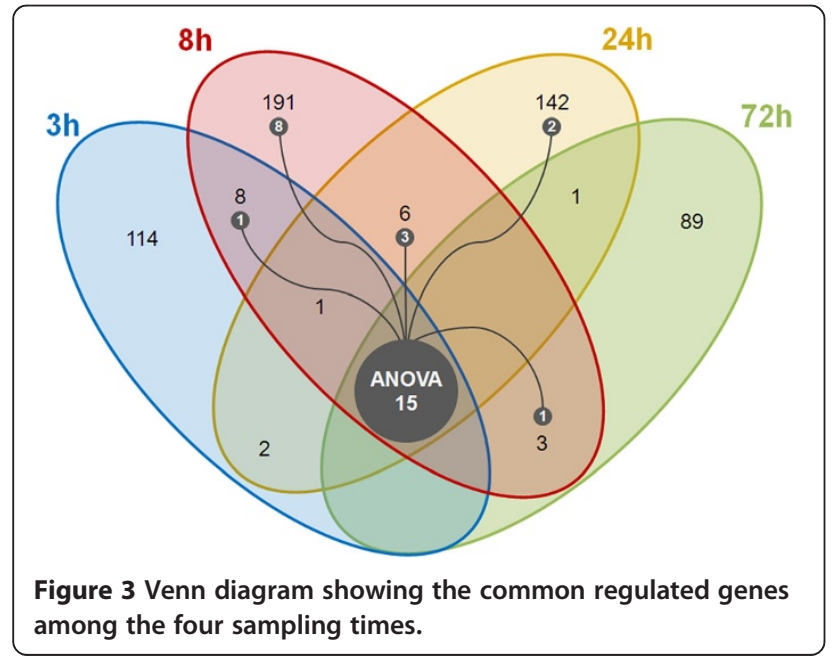

healing (pathogenesis-related protein 5, defense protein precursor and pro-neuregulin-2 membrane bound isoform) or metabolism (udp-glucose 4-epimerase) are included. Several processes were maintained from 3 hours to 8 hours, such as transcription (NF-kB p105 subunit) or recognition (peptidoglycan-recognition protein sb1 precursor (PGRP) and fibrinogen-related protein (FREP)). The expression of FREPs agrees with results reported in the mussel after a bacterial infection in which the maximum expression was obtained after 6 hours postinfection [19]. This result means that while the signaling is maintained because of the pathogen adhesion and recognition, the immune response seems to be initiated. The three immune-related molecules with C1q domains in the list were found to be downregulated. This effect could occur because C1q up-regulation is a very fast mechanism in molluscs as suggested by Gestal et al. [41]. 

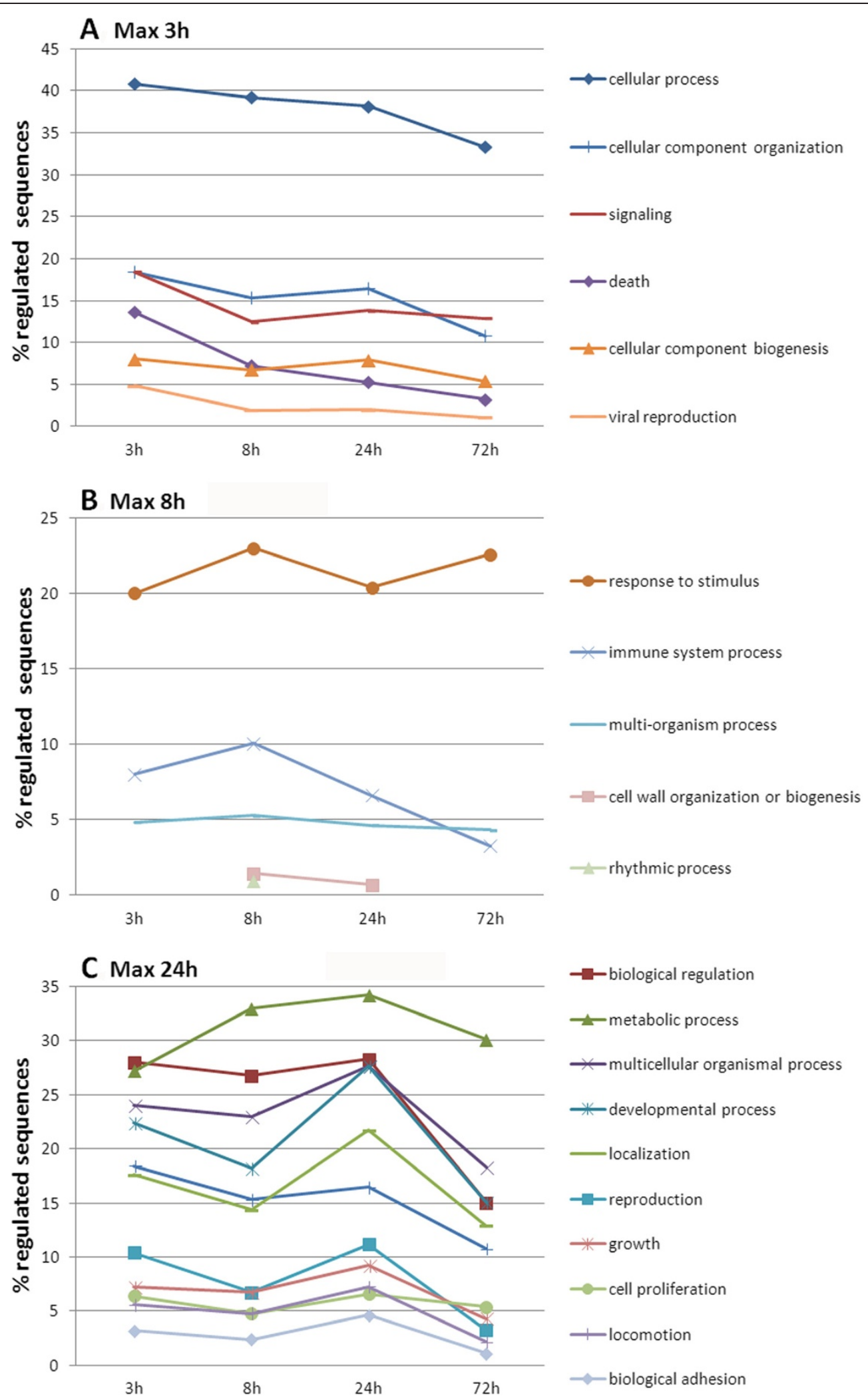

Figure 4 Biological process $\mathrm{GO}$ terms change in regulated genes through time. Numbers in abscissa refer to the percentage of GO term hits of the total of regulated sequences. GO terms with maximum representation in each sampling point are separately represented. A: $3 \mathrm{~h}$, B: $8 \mathrm{~h}$ and C: 24 h. No GO processes exhibited a maximum representation 72 hours post-challenge. 
Table 2 Top 25 expressed genes along the time course

\begin{tabular}{|c|c|c|c|}
\hline Sequence description & 3 hpc FC & Sequence description & 24 hpc FC \\
\hline Dynein light chain flagellar outer arm & 48.91 & Mariner mos 1 transposase & 13.2 \\
\hline Interleukin-17D & 23.7 & pdz and lim domain 5 & 6.31 \\
\hline Ras-related c3 botulinum toxin substrate 3 & 11.05 & Zygote arrest protein 1 & 5.62 \\
\hline Barrier-to-autointegration factor & 10.81 & Monomeric sarcosine oxidase & 5.57 \\
\hline Prothrombin & 9.93 & Cytochrome c-type heme lyase & 5.45 \\
\hline Perlucin & 7.94 & Titin & 5.27 \\
\hline Cubilin & 6.23 & Twitchin & 4.77 \\
\hline Ets-related transcription factor elf-5 & 6.19 & Pin2 terf1-interacting telomerase inhibitor 1 & 4.43 \\
\hline Pre-mrna-splicing factor cwc24 & 5.28 & Leukocyte receptor cluster member 1 homolog & 4.34 \\
\hline Adp-ribosyl cyclase & 5 & SART-3 & 4.19 \\
\hline Insoluble matrix shell protein 5 & 4.81 & Myosin heavy striated muscle & 4.03 \\
\hline MAPKKK1 & 3.92 & Galaxin & 3.45 \\
\hline Heat shock protein 70 & 3.91 & Thap domain-containing protein 9 & 3.23 \\
\hline 40s ribosomal protein s 12 & 3.59 & Calponin 3 & 3.09 \\
\hline HMG box transcription factor Sox 17 & 3.57 & Microtubule-associated protein futsch & 2.94 \\
\hline LTBP-4 & 3.56 & Nuclear speckle splicing regulatory protein 1 & 2.94 \\
\hline Histone acetyltransferase kat6a & 3.54 & Staphylococcal nuclease dom-cont protein 1 & 2.92 \\
\hline Calmodulin & 3.46 & Peroxisomal sarcosine oxidase & -6.9 \\
\hline Nucleolar complex protein 4 homolog & 3.33 & Mosc domain-containing protein mitochondrial & -4.03 \\
\hline Phosphoinositide 3-kinase adapter protein 1 & 3.27 & Aldose 1-epimerase & -3.88 \\
\hline Cytochrome p450 2d6 & 3.21 & Nuclease harbi1 & -3.8 \\
\hline Electron transfer flavoprotein & -67.28 & Lysocardiolipin acyltransferase 1 & -3.34 \\
\hline Complement component c3 & -12.03 & Nuclear pore complex protein nup107 & -3.17 \\
\hline Chaperonin & -6.62 & Hamartin & -3.09 \\
\hline Collagen alpha-1 chain precursor & -3.17 & Selectin & -2.95 \\
\hline Sequence description & 8 hpc FC & Sequence description & 72 hpc FC \\
\hline Ganglioside gm2 activator & 25.86 & Mantle gene 6 & 52.66 \\
\hline Udp-glucose 4-epimerase & 17.86 & Serum amyloid a-3 protein precursor & 19.53 \\
\hline Probable cubilin precursor & 13.74 & Elongation factor 1-gamma & 7.95 \\
\hline Ets domain-containing protein elk-3 & 10.09 & Biotin carboxylase & 7.14 \\
\hline tnf receptor-associated factor 6 & 9.69 & Kazal-type proteinase inhibitor protein & 6.96 \\
\hline Nuclear factor nf-kappa-b p105 subunit & 9.49 & Abc transporter related protein & 5.55 \\
\hline n-acylethanolamine-hydrolyzing acid amidase & 9.44 & Fizzy-related protein homolog & 3.36 \\
\hline Pathogenesis-related protein 5 & 8.81 & Nadh dehydrogenase 1 alpha subcomplex & 2.47 \\
\hline Transmembrane protein 205 & 7.14 & Sarcoplasmic calcium-binding protein & -25.5 \\
\hline Peptidyl-prolyl cis-trans isomerase b & 6.64 & High-affinity Na-dependent carnitine cotransporter & -17.69 \\
\hline Pro-neuregulin-2 membrane-bound isoform & 6.42 & Aragonite-binding protein & -12.9 \\
\hline Defense protein & 5.56 & Cytidine deaminase & -12.29 \\
\hline Peptidoglycan-recognition protein & 4.94 & Cat eye syndrome critical region protein 5 & -9.37 \\
\hline Ficolin-2 & 4.85 & Aldehyde cytosolic 2 & -8.3 \\
\hline Cerebellin-3 & -46.98 & Lysozyme & -7.67 \\
\hline 17-beta-hydroxysteroid dehydrogenase 14 & -18.9 & Glutamine synthetase/glutamate decarboxylase & -6.71 \\
\hline Complement c1q TNF-related protein 6 & -12.62 & Lambda-crystallin & -5.72 \\
\hline Ureidoglycolate hydrolase & -12.39 & Organic cation transporter 1 & -5.17 \\
\hline
\end{tabular}


Table 2 Top 25 expressed genes along the time course (Continued)

\begin{tabular}{lll}
\hline Sodium-dependent serotonine & $\mathbf{- 1 2 . 0 2}$ & Dna-directed rna polymerase ii subunit rpb3 \\
Cytochrome p450 2u1 & $\mathbf{- 9 . 1 9}$ & Monocarboxylate transporter 5 \\
Organic cation transporter protein & $\mathbf{- 7 . 4 4}$ & Cholinesterase \\
Chitotriosidase & $\mathbf{- 7 . 4 1}$ & Muscle lim protein 1 \\
Protein acn9 mitochondrial precursor & $\mathbf{- 6 . 8 9}$ & Probable 4-hydroxy-2-oxoglutarate mitochondrial \\
Clq domain containing protein & $\mathbf{- 6 . 8 4}$ & Protein nlrc3-like \\
N-acetylneuraminate lyase & $\mathbf{- 5 . 5 3}$ & Beta-microseminoprotein \\
\hline
\end{tabular}

In bold, downregulated transcripts.

The major diversity of the processes found by the GO terms occurred one day after the Vibrio challenge (Figure 4C). General functions such as biological regulation or metabolism seemed to peak at this time point. Other processes such as development, localization (the process in which a cell, a macromolecule or an organelle is transported to and/or maintained in a specific location), reproduction, growth, cell proliferation, locomotion and biological adhesion were also important $24 \mathrm{hpc}$. These specific processes are closely related and could indicate the resolution of the challenge after the expression of the immune genes that were triggered at 8 hours. Locomotion and biological adhesion appeared together in the time course because these two processes are intimately related and lead to taxis and migration. In zebrafish, it is known that the chemotaxis of immune cells begins quickly and lasts for several days after an inflammatory stimulus (tailfin transection). Neutrophils are rapidly recruited with a maximum cell count at $6 \mathrm{~h}$ post injury, and the recruitment of macrophages progressively increases until at least $48 \mathrm{~h}$ after injury [42]. The temporal response of $R$. philippinarum hemocytes seems to be intermediate between these two vertebrate cell types. However, the cytoskeleton stays active, which suggests that locomotion is a very dynamic process with a high percentage of the topregulated genes (Table 2, 24 hpc) such as titin, twitchin or calponin-3. In non muscular cells, as the hemocytes, titin has been shown to be related to chromosome condensation and segregation during mitosis [43]. This activity could be indicative of hemocyte proliferation and other upregulated processes, such as development. Furthermore, other functions are upregulated, such as transcription (staphylococcal nuclease domain-containing protein 1), or downregulated, such as metabolism or transport (aldose 1-epimerase, nuclear pore complex protein nup107).

Three days after the challenge, many genes were downregulated, suggesting negative feedback of the majority of the activated genes (Table 2, $72 \mathrm{hpc}$ ). Figure 4 also showed that the GO analysis could not find any processes with a maximum representation 72 hours post-challenge. Metabolism, adhesion, cytoskeleton modulation, transcription and defense (lysozyme) returned to basal levels, which was also illustrated by the general expression pattern shown in
Figure 2. Curiously, the most upregulated gene, mantle gene 6 , is related to the biomineralization of the shell [44]. This result could suggest that after the infection is controlled, the clams refocus the genetic machinery to other matters, such as shell repair. This result agrees with the GO analysis, and all of the biological functions began to stabilize three days after the bacterial challenge.

Because the defense against pathogens in molluscs relies on the innate immune system the response is expected to be fast, to overcome the infections as soon as possible. The contrary often means that the organisms will die. In fact, the critical point of the experiment seemed to be 8 hours after the challenge, when many immune genes were upregulated. Regulation of the apoptotic processes in hemocytes was also triggered early after the challenge and barely no genes related to apoptosis were found 3 days after the challenge. On the other hand, some effector genes such as C3, C1q, defense protein, and lysozyme seemed to exert their function before $24 \mathrm{hpc}$; cathepsins, proteases and protease inhibitors were up or downregulated throughout all the challenge pointing to complex interactions between bacteria and clams. These findings suggest that the survival or death of the animals is decided very early after the challenge, suggesting the importance of a fast triggering of the defense mechanisms.

\section{Enrichment analysis}

A Fisher's exact test was performed to detect any significant enrichment of GO terms in each sampling point and regulation in comparison with the reference set of sequences present in the microarray. Only three analyses were enriched in specific GO terms compared with the entire microarray output: 3 hours upregulated (45 enriched GO terms), 8 hours downregulated (3 terms) and 72 hours downregulated (2 terms). After using the blast2GO tool to reduce the GO enriched terms, the most specific terms (the highest level GO terms of a parental line) were presented in Figure 5. It can be observed that the first significantly enriched processes of the upregulated genes were exclusively related to immune signaling and transcription, such as the toll-like receptor pathway or the regulation of NF-kB import to nucleus. An interesting result was the negative regulation of the IL-8 


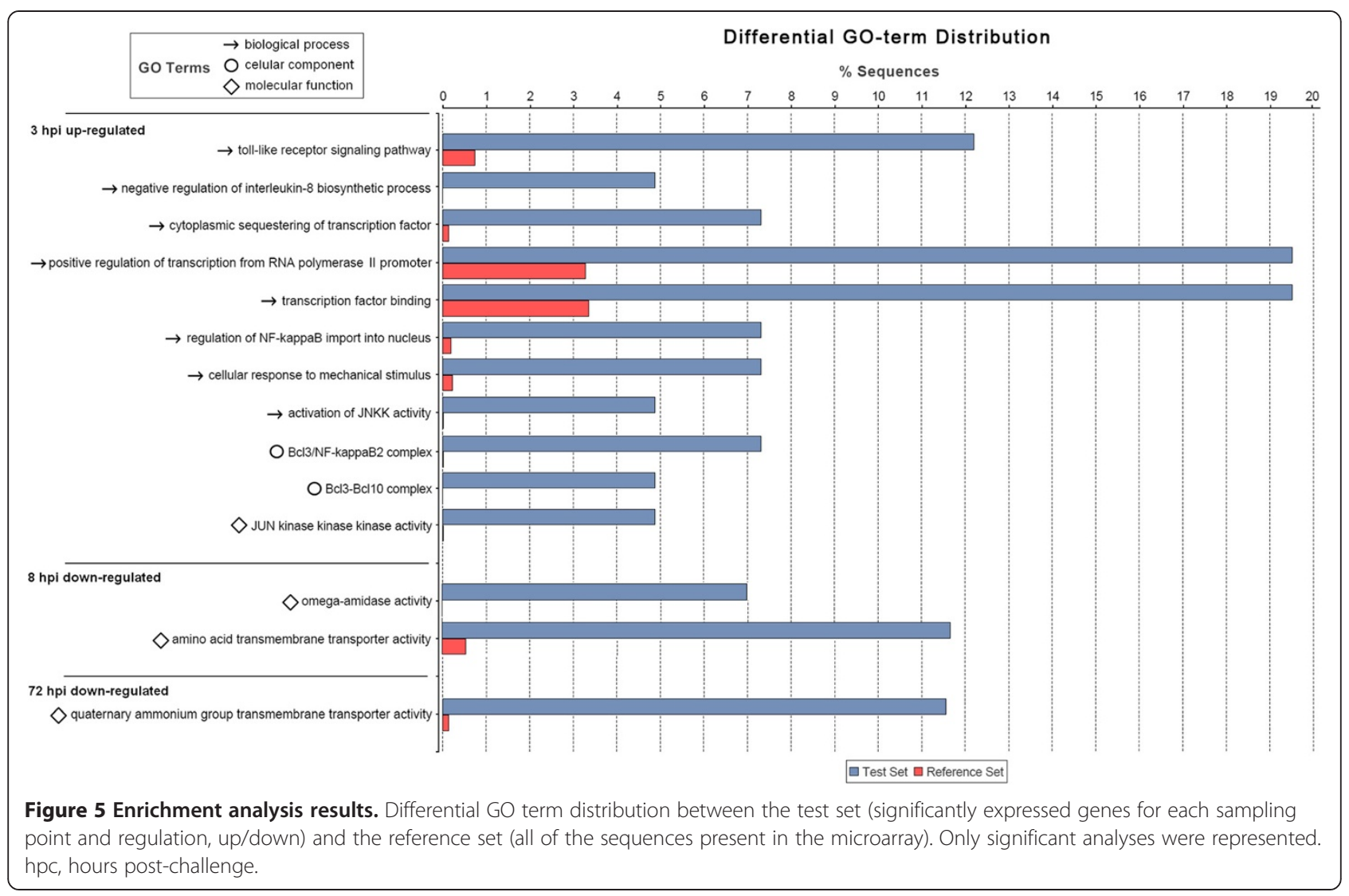

biosynthetic process, which is an indicator of an inhibition of the pro-inflammatory response. These results confirmed the previous findings of the GO annotation and the topexpressed genes, which showed an initial activation of the signaling and transcriptional processes and a strong inhibition of pro-inflammatory molecules such as C3, which seemed to exert their function much earlier than 3 hours after the stimulus, a trait that has been previously observed in bivalves [32].

The enrichment results at 8 hours and 72 hours postchallenge show that only downregulated processes related to metabolism and transport were found, but no specific enrichment of immunity genes was observed. These results imply the importance of an early response and an effective innate immune system in these bivalves.

\section{ANOVA analysis: effect of the challenge in all of the experimental data}

An ANOVA was performed to globally analyze the information of the microarray experiments after the challenge. Although a vast majority of the genes were regulated at a single sampling point, the ANOVA results showed a total of 15 genes that were significantly regulated throughout the time course. Table 3 summarizes a description of the 10 successfully annotated genes with their respective fold changes. The expression profile of the ten genes coincides with the observed pattern in Figure 1: the maximum fold change is achieved 8 hours after the bacterial challenge (except for LTBP4, whose maximum expression comes out at 24 hours). This finding suggests that the highest modulation of expression happens at $8 \mathrm{hpc}$. Thus, that time point after the challenge could represent the actual time point in which the fate of the surviving and dying animals is set.

These ten genes have important defense, protective and homeostasis functions, including cell death and apoptosis, that are key events to decide survivorship of the challenged clams: The phosphoinositide 3-kinase adapter protein 1 (PIK3AP1 or BCAP) links Toll-like receptor signaling and $\mathrm{PI} 3 \mathrm{~K}$ activation, preventing excessive inflammatory cytokine production and contributing to B-cell development in humans $[45,46]$, this could mean that as the same time that defense cells produce an immune response, this is being controlled to avoid self-damage by an uncontrolled inflammatory reaction. The nuclear receptor dax-1 (NR0B1) is a co-regulatory inhibitor of the transcriptional activity of other nuclear receptors. NR0B1 is also related to the development and maintenance of stem cell pluripotency and lipogenesis and gluconeogenesis [47], important processes to maintain the energy homeostasis necessary to overcome an infection and regenerate damaged tissues. LTBP-4, described in the validation of the 
Table 3 Differentially expressed genes detected by ANOVA and regulation after $V$. alginolyticus challenge

\begin{tabular}{|c|c|c|c|c|}
\hline & $3 \mathrm{~h} \mathrm{FC}$ & $8 \mathrm{~h} \mathrm{FC}$ & 24 h FC & $72 \mathrm{~h} \mathrm{FC}$ \\
\hline \multicolumn{5}{|l|}{ Immune effectors } \\
\hline Latent-transforming growth factor beta-binding protein 4 & 3.55 & 43.50 & 217.29 & 3.49 \\
\hline Heat shock 70 kda protein & 1.31 & 5.30 & 2.18 & -1.39 \\
\hline Phosphoinositide 3-kinase adapter protein 1 & 3.27 & 5.56 & 2.06 & -1.13 \\
\hline Tnf receptor-associated factor 6 & 2.47 & 9.69 & 2.36 & -1.27 \\
\hline \multicolumn{5}{|l|}{ Recognition/adhesion } \\
\hline Perlucin-like protein & 7.94 & 39.44 & 29.44 & 19.91 \\
\hline Protein lin-7 homolog c & -1.29 & -2.37 & -2.26 & -1.25 \\
\hline \multicolumn{5}{|l|}{ Transcription } \\
\hline Nuclear receptor dax-1 & 2.18 & 4.02 & 2.85 & 1.06 \\
\hline Ets-related transcription factor elf- 5 & 6.19 & 26.84 & 10.00 & 1.35 \\
\hline Nuclear factor nf-kappa-b p50 subunit & 1.74 & 9.48 & 1.89 & -1.33 \\
\hline A20-binding inhibitor of nf-kappa-b activation 2 & 1.98 & 3.37 & 1.77 & -1.13 \\
\hline
\end{tabular}

microarray, modulates TGF- $\beta$ activity and is related to cell adhesion and migration. The perlucin-like protein is a constitutive and regulating C-type lectin that promotes calcium carbonate precipitation and crystallization. Perlucin contains a carbohydrate recognition domain, and because this protein is expressed both in the mantle and in the gills and the digestive tract, it has been suggested that perlucin could play a role in non-self antigen recognition, similarly to other C-type lectins to trigger the immune response [48]. The upregulation of heat shock proteins (HSPs) represents an important mechanism in the stress response and their functions are closely linked to the innate immune system. Although the primary role of HSP70 is to function as a molecular chaperone, it inhibits the mitochondrial apoptosis pathway as well [49], a signal of the changes being produced after the Vibrio challenge and the survival efforts of hemocytes to overcome the infection. TRAF6, which has been described previously, is a signaling molecule that leads to the activation of the NF-kB and AP-1 transcription factors implicated in the regulation processes such as cell proliferation and survival, growth, differentiation, apoptosis, cell migration or metabolism; all of them closely related to immunity and response to a pathogen. The protein lin-7 homolog c establishes and maintains the distribution of channels and receptors at the plasma membrane of epithelial cells [50] and is likely to be involved in the formation of the cadherin-independent tight junctionlike structure in epithelial cells and in the synapses in mammals [51], suggesting a role in establishment of the hemocytes adhesion to other cells and maybe intercellular signal transductions after the Vibrio challenge. The last three genes are a group related to transcription: the etsrelated transcription factor elf-5, a transcriptional activator restricted to epithelial cells and involved in the keratinocyte differentiation in mammals [52], the NF-kB p50 subunit and the a20-binding inhibitor of NF- $\mathrm{kB}$ activation 2, two molecules that are implicated in the NF- $k B$ signaling pathway, which controls many inflammatory and immune responses, cell proliferation, apoptosis and metabolism [53,54]. These molecules are closely involved in defense against pathogens, from recognition to effector functions in the immune system. Additionally, cell proliferation, survival or death were very represented processes, showing that apoptotic/antiapoptotic molecules are highly expressed after a Vibrio challenge, indicative of the active fight of the hemocytes.

\section{Functional immune response of hemocytes after bacterial infection}

To finally evaluate if the changes in gene expression corresponded to functional parameters, the immune response triggered by the $V$. alginolyticus infection was evaluated. In primary cultures of clam hemocytes (granulocytes and hyalinocytes) (Figure 6A), the in vitro infection with $V$. alginolyticus induced apoptotic and necrotic cell death $1 \mathrm{~h}$ after infection (Figure 1B). This functional result agrees with the GO analysis showing that most significantly upregulated genes at the beginning of the infection could be involved in chemotaxis, adhesion and therefore they lead to a rapid triggering of several mechanisms, such as apoptosis.

Results obtained after the intramuscular injection of $V$. alginolyticus also supported the previous findings of the GO annotation and the top-expressed genes. This bacterial infection induced significant changes in the cell concentration in hemolymph extracted from the site of infection. This parameter is an indirect indicator of cell migration to the site of infection. As soon as $6 \mathrm{~h}$ after infection the cell concentration registered in infected animals was significantly higher than that registered in 


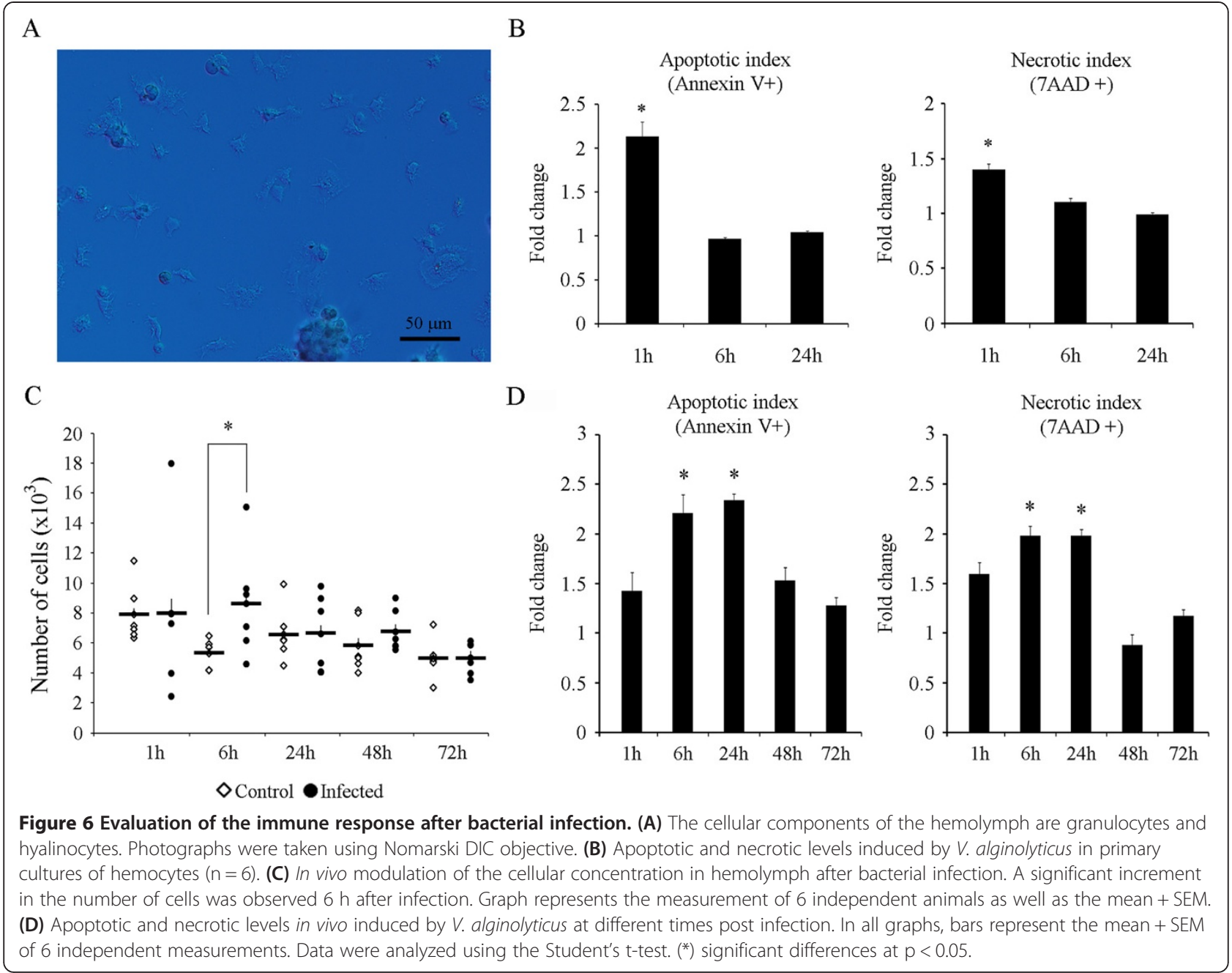

controls. Cell migration seemed to be a quickly response since no significant variations were registered at 24,48 and $72 \mathrm{~h}$ (Figure 6C). V. alginolyticus was also able to induce cell death after in vivo infections, although the timing for induction was different to that observed in cell cultures. A significant increment in the number of necrotic and apoptotic cells was registered at 6 and $24 \mathrm{~h}$ post-infection (Figure 6D).

\section{Conclusions}

The current work presents the second version of the $R$. philippinarum oligo-microarray enriched with immune sequences from hemocytes. We have analyzed the response of the Manila clam, $R$. philippinarum, after a $V$. alginolyticus challenge, strain TA15, and found almost 600 differentially expressed genes out of 13,671 probes. After the expression, GO term analyses and functional immune studies, we were able to establish a putative timing for a Vibrio infection in clams: there was an early response (3 hours) of hemocytes against the Vibrio challenge in which the main functions of hemocytes were mainly related to cellular component organization, biogenesis, cell migration, signaling and death. These functions were a fast response to the pathogen with related genes such as IL-17 or calmodulin. Eight hours seemed to be a key point in time to overcome the bacterial challenge, as the most important functions were related to response to stimulus, the immune system process and the multi-organism process to directly initiate the defense. Genes such as PGRPs, FREPs and defense proteins were present at this sampling point. After one day, there was a modulation of a great number of functions, from general processes such as metabolism to more specific functions such as development, localization and locomotion. Many cytoskeleton genes were found between the top-expressed genes, which is indicative of a possible chemotactic response in hemocytes. Finally, after 72 h, the number of regulated genes decreased substantially, indicating a stabilization of the status of the clam and the end of the cellular response to the challenge. We have to take into account that the modulation of the genes can be the result of an effective immune response but also a symptom of a 
future death. In fact, several apoptotic and anti-apoptotic genes were regulated. This highlights that the obtained transcriptomic profile is a reflection of a complex interaction between the host immune system and the pathogen that deserves further studies.

In summary, bivalves are able to respond quickly against an infection with an orchestrated modulation of different genes. The immune-enriched oligo-microarray for $R$. philippinarum has proven to be useful in hemocyte expression analysis, and this tool has yielded interesting results.

\section{Methods}

Sequence assembly, annotation and microarray design A total of 1,438,665 sequences from $R$. philippinarum were collected from different origins: 454 sequencing and Sanger sequencing $[20,21]$ and available ESTs in the NCBI database. Table 1 details the number of sequences by origin, assembly and annotation criteria. After removing low-quality sequences and filtering for adaptors and primers, the cured sequences were assembled using the Newbler software package (GS De Novo Assembler v2.6, Roche). BlastX and BlastN algorithms [55] (http://blast. ncbi.nlm.nih.gov/Blast.cgi) were used to annotate the selected sequences. Alignments with an e-value threshold of $10^{-3}$ and $10^{-5}$ were considered significant for protein and nucleotide databases, respectively. The reference databases that were used are NCBI SwissProt, NCBI Metazoan RefSeq, NCBI nonredundant and ENSEMBL databases, and the dedicated databases for B. glabrata (http://www. snaildb.org/) and L. gigantea (http://genome.jgi-psf.org/ Lotgi1/Lotgi1.download.html).

Probe design was carried out using the Agilent eArray interface (https://earray.chem.agilent.com/earray/), which applies proprietary prediction algorithms to design 60-mer oligoprobes.

Microarrays were synthesized in situ using the Agilent ink-jet technology with an $8 \times 15 \mathrm{~K}$ format. Each array included default positive and negative controls. Probe sequences and other details on the microarray platform can be found in the GEO database (http://www.ncbi. nlm.nih.gov/geo/) [56] under accession number GPL16450. The GEO accession for the series data (microarray gene expression data) is GSE43274.

\section{Animal sampling and RNA isolation}

$R$. philippinarum clams were obtained from a commercial shellfish farm (Vigo, Galicia, Spain). Clams were maintained in open circuit filtered sea water tanks at $15^{\circ} \mathrm{C}$ with aeration and were fed daily with Phaeodactylum tricornutum and Isochrysis galbana. Prior to the experiments, the clams were acclimatized to the aquarium conditions for one week.
Clams $(n=100)$ were notched in the shell and injected in the muscle with $100 \mu \mathrm{l}$ of $10^{8} \mathrm{CFU} / \mathrm{ml}$ of Vibrio alginolyticus, strain TA15. The inoculation dose was chosen according to previous Vibrio challenges in $R$. philippinarum $[5,18,57]$. Controls $(\mathrm{n}=100)$ were injected with $100 \mu \mathrm{l}$ of PBS. After challenge, the clams were returned to the tanks and maintained at $15^{\circ} \mathrm{C}$ until sampling at 3 , 8,24 , and 72 hours after challenge. The cumulative mortality rate at the end of the experiment, 72 hours, was $44 \%$. The controls showed an end point mortality of $10 \%$.

Hemolymph $(1 \mathrm{ml})$ was withdrawn from the adductor muscle of the clams with a $0.5 \mathrm{~mm}$ diameter (25 G) disposable needle. Hemolymph from four individuals was pooled, and five biological replicates were taken at each sampling point. The hemolymph was centrifuged at $3000 \mathrm{~g}$ for 10 minutes at $4^{\circ} \mathrm{C}$. The pellet was resuspended in $250 \mu \mathrm{l}$ of TRIzol (Invitrogen). Total RNA isolation was conducted following the manufacturer's specifications in combination with the RNeasy Mini kit (Qiagen) for RNA purification after DNase I treatment. Next, the concentration and purity of the RNA were measured using a NanoDrop ND1000 spectrophotometer. Finally, RNA integrity was tested on an Agilent 2100 Bioanalyzer (Agilent Technologies). Only the samples with high RNA quality were used for labeling and hybridization, 3 to 5 biological replicates were used for each condition and time.

\section{Cy3 labeling}

Sample labeling and hybridization were performed according to the Agilent One-Color Microarray-Based Gene Expression Analysis protocol. Briefly, 100 ng of RNA from each RNA sample was amplified and labeled with Cy3 using the Low Input Quick Amp labeling kit (Agilent Technologies), according to the manufacturer's instructions. Each sample included a mixture of 10 different viral poly-acetylated RNAs (Agilent Spike-In Mix) before amplification and labeling so the microarray analysis workflow could be assessed. Qiagen RNeasy mini spin columns were used to purify amplified RNA. Finally, amplification and dye incorporation rates were verified using a NanoDrop ND1000 spectrophotometer. These values should be between 200 and $500 \mathrm{ng} / \mu \mathrm{L}$ (RNA concentration) and between 20 and $50 \mathrm{pmol} / \mu \mathrm{g}$ aRNA (dye incorporation).

\section{Microarray hybridization and analysis}

Cy3 labeled RNA (600 ng) was fragmented with $5 \mu$ of 10x Blocking Agent and $1 \mu \mathrm{l}$ of $25 \times$ Fragmentation Buffer at $60^{\circ} \mathrm{C}$ for $30 \mathrm{~min}$. Finally, $55 \mu \mathrm{l}$ of $2 \times$ GE Hybridization buffer was added to dilute the fragmented RNA. The eight spaces of the gasket slide were filled with $40 \mu \mathrm{l}$ of the correspondent hybridization solution and then assembled on the microarray slide (each slide contained eight arrays). Slides were incubated for $17 \mathrm{~h}$ at $65^{\circ} \mathrm{C}$ in an Agilent Hybridization Oven, subsequently removed from 
the hybridization chamber, quickly submerged in GE Wash Buffer 1 to disassemble the slides and then washed in GE Wash Buffer 1 for 1 minute followed by one additional wash in pre-warmed $\left(37^{\circ} \mathrm{C}\right) \mathrm{GE}$ Wash Buffer 2 .

Hybridized slides were scanned at $5 \mu \mathrm{m}$ resolution using an Agilent G2565BA DNA microarray scanner. Default settings were modified to scan the same slide at two different sensitivity levels (XDR Hi $100 \%$ and XDR Lo 10\%). The two linked images generated were analyzed together, the data were extracted, and the background was subtracted using the standard procedures in the Agilent Feature Extraction Software version 9.5.1. The software returned a series of spot quality measures to evaluate the goodness and the reliability of the spot intensity estimates. After ensuring that all of the microarrays passed the quality tests (spatial distribution of median signals for row and column, distribution of the spot signal, spatial distribution of all outliers of the array, coefficient of variation of the technical replicates of the SpikeIn and the regression correlation between signal and concentration) (Additional file 2: 1-36), control features (positive, negative, etc.), except for SpikeIn Viral RNAs, were excluded from subsequent analyses. SpikeIn control intensities were used as internal controls and were expected to be uniform across the experiments of a given dataset.

The GeneSpring software (Agilent) was used to normalize and analyze the microarray fluorescence data. To identify regulated genes, two statistical analyses in filtered raw data $\left(20-90^{\text {th }}\right.$ Percentile) were carried out: a t-test $(\mathrm{p}<0.01)$ and a two-way ANOVA $(\mathrm{p}<0.05)$ with a Benjamini-Hochberg multiple testing correction. The t-test was used to find the genes that were significantly different between the controls and the infected samples at each sampling point. Genes with a fold change between \pm 1.5 were not used for further investigation. ANOVA analysis was performed to analyze the whole dataset taking into account the challenge along all the sampling times.

\section{GO terms and enrichment analysis}

After statistical analysis, blast2GO software [58] was used to assign GO terms [59] to the significantly expressed genes ( $\mathrm{t}$-test, $\mathrm{p}<0.01$ ) through the time course. Default values (annotation cutoff $=55$, GOweight $=5$ ) in blast $2 \mathrm{GO}$ were used to perform the analysis and biological process ontology level 2 was selected.

The enrichment analyses were made with the total microarray information as the reference set and each sampling time ( $3 \mathrm{~h}, 8 \mathrm{~h}, 24 \mathrm{~h}, 72 \mathrm{~h}$ ) and regulation (up or down) as the test sets. Then, Fisher's exact test was run with default values: a one-tailed test without removing double IDs and 0.05 false discovery rate (FDR) cutoff. To construct Figure 5, the blast2GO option to show only the most specific terms (0.05 FDR cut-off) was performed.

\section{Validation of the microarray}

Specific PCR primers were designed from the sequences of the selected probes (Table 4) using the Primer3 program [60] according to qPCR restrictions. Oligo Analyzer 1.0.2 was used to check for dimer and hairpin formation. The efficiency of each primer pair was then analyzed with seven serial five-fold dilutions of cDNA of $R$. philippinarum and was calculated from the slope of the regression line of the quantification cycle versus the relative concentration of cDNA [61]. A melting curve analysis was also performed to verify that only specific amplification occurred and that no primer dimers were amplified. If these conditions were not satisfied, new primer pairs were designed.

The cDNA synthesis was performed on $1 \mu \mathrm{g}$ of total RNA using SuperScript ${ }^{\mathrm{Tm}}$ III Reverse Transcriptase (Invitrogen) following the manufacturer's protocol. The same RNAs used for hybridization of the microarrays were used for the retrotranscription.

Real-time quantitative PCR was performed in the 7300 Real Time PCR System (Applied Biosystems).

Table 4 Primers designed for the microarray validation

\begin{tabular}{|c|c|c|c|c|c|}
\hline Primer name & Sequence $5^{\prime} \rightarrow 3^{\prime}$ & $\mathrm{Tm}$ & Product size & Ct slope & Acc. $n^{\circ} /$ Probe name \\
\hline Clam 18S F & CCGAACATCTAAGGGCATCA & 60.12 & $169 \mathrm{bp}$ & -3.0 & EF426293.1 \\
\hline Clam 18S R & AGTTGGTGGAGCGATTTGTC & 60.99 & & & \\
\hline $\mathrm{C} 3 \mathrm{~F}$ & CCCAGGTGCCAAAGAACA & 55.56 & $162 \mathrm{bp}$ & -3.5 & S_isotig17547_isogroup06014 \\
\hline C3 R & GCGGGGTACACATACTCGTC & 60.00 & & & \\
\hline IL-17D F & CTCAAAAAGACTCACAGGGAATG & 60.15 & $186 \mathrm{bp}$ & -3.8 & P_isotig09595_isogroup01099 \\
\hline IL-17D R & CTGGCAATGATGTACTGTCGTAA & 60.07 & & & \\
\hline LTBP-4 F & TAATCATTGCCGCCTTATCG & 60.92 & $188 \mathrm{bp}$ & -3.6 & S_isotig21547_isogroup10014 \\
\hline LTBP-4 R & GCGACCTGAATCAAATTCGT & 60.08 & & & \\
\hline TRAF6 F & GCCAACATAGTAGCTCAGGAACA & 60.68 & $148 \mathrm{bp}$ & -3.4 & P_isotig17929_isogroup06396 \\
\hline TRAF6 R & TTCCAATATAGCTTACAACATCAACA & 59.08 & & & \\
\hline
\end{tabular}


One microlitre of fivefold-diluted cDNA template was mixed with $0.5 \mu \mathrm{l}$ of each primer $(10 \mu \mathrm{M})$ and $12.5 \mu \mathrm{l}$ of SYBR Green PCR master mix (Applied Biosystems) in a final volume of $25 \mu$ l. The standard cycling conditions were $95^{\circ} \mathrm{C}$ for $10 \mathrm{~min}$, followed by 40 cycles of $95^{\circ} \mathrm{C}$ for 15 seconds and $60^{\circ} \mathrm{C}$ for 30 seconds. All reactions were performed as technical triplicates, and an analysis of melting curves was performed in each reaction. The relative expression levels of the genes were normalized using $18 \mathrm{~S}$ as a reference gene, which was constitutively expressed and not affected by the Vibrio challenge, following the Pfaffl method [61].

\section{Functional immune response of hemocytes after bacterial infection}

The immune response triggered after $V$. alginolyticus infection was evaluated through in vitro as well as in vivo experiments. Flow cytometry was used to evaluate different immune parameters such as cell migration and bacterialinduced apoptosis.

For in vitro experiments hemolymph from 12 animals were diluted 1:1 in ice-cold filtered sea water to prevent aggregation and dispensed $(200 \mu \mathrm{l})$ into 24 wells plates. After $30 \mathrm{~min}$ of incubation at $15^{\circ} \mathrm{C}$ in the dark for cell adhesion, cells were infected with $200 \mu \mathrm{l}$ of the TA15 strain $V$. alginolyticus $\left(10^{8} \mathrm{CFUs} / \mathrm{ml}\right)$ and maintained at $15^{\circ} \mathrm{C}$. Induction of apoptosis was evaluated $1 \mathrm{~h}, 6 \mathrm{~h}$ and $24 \mathrm{~h}$ after infection in six different cell cultures. Supernatants were removed and $500 \mu \mathrm{l}$ of ice-cold binding buffer (10 mM Hepes/NaOH, pH 7.4, $140 \mathrm{mM} \mathrm{NaCl}$, $2.5 \mathrm{mM} \mathrm{CaCl}_{2}$ ) containing $5 \mu \mathrm{l}$ Annexin V-FITC (BD Biosciences) and $10 \mu \mathrm{l}$ of 7-amino-actinomycin D (7AAD, BD Biosciences) were added. Cells were incubated for $15 \mathrm{~min}$ in the dark and analyzed in a FACSCalibur flow cytometer using Cell Quest software (BD Biosciences). The apoptotic process was evaluated using the FITC and 7AAD content detected in the FL-1 $(530 \mathrm{~nm})$ and FL-3 $(650 \mathrm{~nm})$ channels, respectively. Fold units were calculated by dividing the percentage of FL-1 positive hemocytes obtained after infection by the values recorded in the control group. In all experiments data were analyzed using the Student's t-test $(\mathrm{p}<0.05)$. Fresh hemocytes were visualized using an Eclipse 80i light microscopy (Nikon) with Nomarski DIC prism to enhance the contrast.

For in vivo experiments 40 clams were intramuscular injected with $100 \mu \mathrm{l}$ of the TA15 strain $V$. alginolyticus $\left(4 \times 10^{10} \mathrm{CFUs} / \mathrm{ml}\right)$. Control animals were injected with the same volume of filtered sea water. Animals were maintained in closed-circuit aquarium at $15^{\circ} \mathrm{C}$. Hemolymph was extracted from 6 infected and 6 control animals at 1 , $6,24,48$ and $72 \mathrm{~h}$ after infection. Samples were immediately diluted 1:1 in ice-cold binding buffer and stained with Annexin V-FITC (BD Biosciences) and 7-aminoactinomycin D (7-AAD, BD Biosciences). Cells were incubated for 15 min in the dark and analyzed by flow cytometry as previously described. Cell migration to the site of infection was estimated by measuring the cell concentration in hemolymph extracted from the infected muscle.

\section{Availability of supporting data}

Microarray data are deposited in the public functional genomics data repository GEO (Gene Expression Omnibus):

- Microarray platform: https://www.ncbi.nlm.nih.gov/geo/query/acc.cgi? acc $=$ GPL16450

- Microarray gene expression data: https://www.ncbi.nlm.nih.gov/geo/query/acc.cgi? acc $=$ GSE 43274

\section{Additional files}

Additional file 1: Description of the reference databases used to annotate $R$. philippinarum sequences.

Additional file 2: Quality control of each microarray experiment provided by the Agilent Feature Extraction Software.

\section{Competing interests}

The authors declare that they have no competing interests.

\section{Authors' contributions}

$\mathrm{BN}$ and $\mathrm{AF}$ conceived and designed the experiments. RM prepared the samples. LB, MM, MB and RM made the assembly and annotation of the sequences and designed the microarray platform. RM and MM hybridized the microarrays. AR performed functional immune assays. BN, AF, PB, AR and RM analyzed the data. RM wrote the paper. All authors read and approved the manuscript.

\section{Acknowledgements}

This work has been partially funded by the EU Project REPROSEED (245119). RM wishes to acknowledge the Spanish MICINN for her FPI Spanish research grant (BES-2009-029765).

\section{Author details}

${ }^{1}$ Instituto de Investigaciones Marinas (IIM), Consejo Superior de Investigaciones Científicas (CSIC), Eduardo Cabello 6, 36208 Vigo, Spain. ${ }^{2}$ Department of Comparative Biomedicine and Food Science (BCA), University of Padova, Viale dell'Università 16, 35020 Legnaro, Italy.

Received: 13 March 2013 Accepted: 31 March 2014 Published: 7 April 2014

\section{References}

1. Gestal C, Roch P, Renault T, Pallavicini A, Paillard C, Novoa B, Oubella R, Venier $P$, Figueras A: Study of diseases and the immune system of bivalves using molecular biology and genomics. Rev Fish Sci 2008, 16:131-154.

2. Paillard C, Leroux F, Borrego JJ: Bacterial disease in marine bivalves, Review of recent studies. Trends and evolution. Aquat Living Resour 2004, 17:477-498

3. Villalba A, Reece KS, Ordás MC, Casas SM, Figueras A: Perkinsosis in molluscs: A review. Aquat Living Resour 2004, 17:411-432.

4. Waki T, Shimokawa J, Watanabe S, Yoshinaga T, Ogawa K: Experimental challenges of wild Manila clams with Perkinsus species isolated from naturally infected wild Manila clams. J Invertebr Pathol 2012, 111:50-55.

5. Allam B, Paillard C, Auffret M: Alterations in hemolymph and extrapallial fluid parameters in the Manila clam, Ruditapes philippinarum, challenged with the pathogen Vibrio tapetis. J Invertebr Pathol 2000, 76:63-69. 
6. Gómez-León J, Villamil L, Lemos ML, Novoa B, Figueras A: Isolation of $V$. alginolyticus and Vibrio splendidus from aquacultured carpet shell clam (Ruditapes decussatus) larvae associated with mass mortalities. Appl Environ Microb 2005, 71:98-104.

7. Canesi L, Gallo G, Gavioli M, Pruzzo C: Bacteria-hemocyte interactions and phagocytosis in bivalves. Microsc Res Technol 2002, 57:469-476.

8. Olafsen JA: Role of lectins (C-reactive protein) in defense of marine bivalves against bacteria. Adv Exp Med Biol 1995, 371A:343-348.

9. Ordás MC, Novoa B, Figueras A: Modulation of the chemiluminescence response of Mediterranean mussel (Mytilus galloprovincialis) haemocytes. Fish Shellfish Immunol 2000, 10:611-622.

10. Ordás MC, Ordás A, Beloso C, Figueras A: Immune parameters in carpet shell clams naturally infected with Perkinsus atlanticus. Fish Shellfish Immunol 2000, 10:597-609.

11. Tafalla C, Gómez-León J, Novoa B, Figueras A: Nitric oxide production by carpet shell clam (Ruditapes decussatus) hemocytes. Dev Comp Immunol 2003, 27:197-205

12. Bayne CJ, Sminia T, Van der Knaap WPW: Immunological Memory: Status of Molluscan Studies. In Phylogeny of Immunological Memory, Developments in immunology, Volume 10. Edited by Manning MJ. Amsterdam: Elsevier; 1980:57-64.

13. Gueguen $Y$, Cadoret JP, Flament D, Barreau-Roumiguiere C, Girardot AL, Garnier J, Hoareau A, Bachere E, Escoubas JM: Immune gene discovery by expressed sequence tags generated from hemocytes of the bacteria-challenged oyster, Crassostrea gigas. Gene 2003, 303:139-145.

14. Costa MM, Novoa B, Figueras A: Influence of $\beta$-glucans on the immune responses of carpet shell clam (Ruditapes decussatus) and Mediterranean mussel (Mytilus galloprovincialis). Fish Shellfish Immunol 2008, 24:498-505.

15. Costa MM, Prado-Alvarez M, Gestal C, Roch P, Li H, Novoa B, Figueras A: Functional and molecular immune response of Mediterranean mussel (Mytilus galloprovincialis) hemocytes against pathogen associated molecular patterns and bacteria. Fish Shellfish Immunol 2009, 26:515-523.

16. Li H, Venier P, Prado-Alvarez M, Gestal C, Toubiana M, Quartesan R, Borghesan F, Novoa B, Figueras A, Roch P: Expression of Mytilus immune genes in response to experimental challenges varied according to the site of collection. Fish Shellfish Immunol 2010, 28:640-648.

17. Araya MT, Markham F, Mateo DR, McKenna P, Johnson GR, Berthe FCJ, Siah A: Identification and expression of immune-related genes in hemocytes of soft-shell clams, Mya arenaria, challenged with Vibrio splendidus. Fish Shellfish Immunol 2010, 29:557-564.

18. Moreira R, Balseiro P, Romero A, Dios S, Posada D, Novoa B, Figueras A: Gene expression analysis of clams Ruditapes philippinarum and Ruditapes decussatus following bacterial infection yields molecular insights into pathogen resistance and immunity. Dev Comp Immunol 2012, 36:140-149.

19. Romero A, Dios S, Poisa-Beiro L, Costa MM, Posada D, Figueras A, Novoa B: Individual sequence variability and functional activities of fibrinogen-related proteins (FREPs) in the Mediterranean mussel (Mytilus galloprovincialis) suggest ancient and complex immune recognition models in invertebrates. Dev Comp Immunol 2011, 35:334-344.

20. Milan M, Coppe A, Reinhardt R, Cancela LM, Leite RB, Saavedra C, Ciofi C, Chelazzi G, Patarnello T, Bortoluzzi S, Bargelloni L: Transcriptome sequencing and microarray development for the Manila clam, Ruditapes philippinarum: genomic tools for environmental monitoring. BMC Genomics 2011, 12:234.

21. Moreira R, Balseiro P, Planas JV, Fuste B, Beltran S, Novoa B, Figueras A: Transcriptomics of in vitro immune-stimulated hemocytes from the Manila clam Ruditapes philippinarum using high-throughput sequencing. PLoS One 2012, 7:e35009.

22. Ghiselli F, Milani L, Chang PL, Hedgecock D, Davis JP, Nuzhdin SV, Passamonti M: De Novo Assembly of the Manila Clam Ruditapes philippinarum Transcriptome Provides New Insights into Expression Bias, Mitochondrial Doubly Uniparental Inheritance and Sex Determination. Mol Biol Evol 2012, 29:771-786.

23. Hughes TR, Mao M, Jones AR, Burchard J, Marton MJ, Shannon KW, Lefkowitz SM, Ziman M, Schelter JM, Meyer MR, Kobayashi S, Davis C, Dai H, He YD, Stephaniants SB, Cavet G, Walker WL, West A, Coffey E, Shoemaker DD, Stoughton R, Blanchard AP, Friend SH, Linsley PS: Expression profiling using microarrays fabricated by an ink-jet oligonucleotide synthesizer. Nat Biotechnol 2001, 19:342-347.

24. Iwahashi H, Kitagawa E, Suzuki Y, Ueda Y, Ishizawa YH, Nobumasa H, Kuboki $Y$, Hosoda $H$, Iwahashi $Y$ : Evaluation of toxicity of the mycotoxin citrinin using yeast ORF DNA microarray and Oligo DNA microarray. BMC Genomics 2007, 8:95.
25. Wang YZ, Han YS, Ma YS, Jiang JJ, Chen ZX, Wang YC, Che W, Zhang F, Xia Q, Wang XF: Differential gene expression of Wnt signaling pathway in benign, premalignant, and malignant human breast epithelial cells. Tumour Biol 2012, 33:2317-2327.

26. Dheilly NM, Lelong C, Huvet A, Favrel P: Development of a Pacific oyster (Crassostrea gigas) 31,918-feature microarray: identification of reference genes and tissue-enriched expression patterns. BMC Genomics 2011, 12:468.

27. Wang S, Peatman E, Liu H, Bushek D, Ford SE, Kucuktas H, Quilang J, Li P, Wallace R, Wang Y, Guo X, Liu Z: Microarray analysis of gene expression in eastern oyster (Crassostrea virginica) reveals a novel combination of antimicrobial and oxidative stress host responses after dermo (Perkinsus marinus) challenge. Fish Shellfish Immunol 2010, 29:921-929.

28. Xu W, Faisal M: Development of a cDNA microarray of zebra mussel (Dreissena polymorpha) foot and its use in understanding the early stage of underwater adhesion. Gene 2009, 436:71-80.

29. Allam B, Tanguy A, Jeffroy F, Le Bris C, Espinosa EP, Paillard C: Transcriptional changes in Manila clam (Ruditapes philippinarum) in response to brown ring disease. Fish Shellfish Immunol 2013, 34:1636.

30. Morey JS, Ryan JC, Van Dolah FM: Microarray validation: factors influencing correlation between oligonucleotide microarrays and real-time PCR. Biol Proced Online 2006, 8:175-193.

31. Dunkelberger JR, Song WC: Complement and its role in innate and adaptive immune responses. Cell Res 2010, 20:34-50.

32. Prado-Alvarez M, Rotllant J, Gestal C, Novoa B, Fiqueras A: Characterization of a C3 and a factor B-like in the carpet-shell clam, Ruditapes decussatus. Fish Shellfish Immunol 2009, 26:305-315.

33. Starnes T, Broxmeyer HE, Robertson MJ, Hromas R: Cutting edge: IL-17D, a novel member of the IL-17 family, stimulates cytokine production and inhibits hemopoiesis. J Immunol 2002, 169:642-646.

34. Costa MM, Pereiro P, Wang T, Secombes CJ, Figueras A, Novoa B: Characterization and gene expression analysis of the two main Th17 cytokines (IL-17A/F and IL-22) in turbot, Scophthalmus maximus. Dev Comp Immunol 2012, 38:505-516.

35. Roberts S, Gueguen Y, de Lorgeril J, Goetz F: Rapid accumulation of an interleukin 17 homolog transcript in Crassostrea gigas hemocytes following bacterial exposure. Dev Comp Immunol 2008, 32:1099-1104.

36. Zhou Y, Koli K, Hagood JS, Miao M, Mavalli M, Rifkin DB, Murphy-Ullrich JE: Latent transforming growth factor-beta-binding protein-4 regulates transforming growth factor-beta1 bioavailability for activation by fibrogenic lung fibroblasts in response to bleomycin. Am J Pathol 2009, 174:21-33.

37. Kantola AK, Keski-Oja J, Koli K: Fibronectin and heparin binding domains of latent TGF-beta binding protein (LTBP)-4 mediate matrix targeting and cell adhesion. Exp Cell Res 2008, 314:2488-2500.

38. Qiu L, Song L, Yu Y, Zhao J, Wang L, Zhang Q: Identification and expression of TRAF6 (TNF receptor-associated factor 6) gene in Zhikong scallop Chlamys farreri. Fish Shellfish Immunol 2009, 26:359-367.

39. Walker MP, Zhang M, Le TP, Wu P, Lainé M, Greene GL: RAC3 is a pro-migratory co-activator of ERa. Oncogene 2011, 30:1984-1994

40. Can G, Akpinar B, Baran Y, Zhivotovsky B, Olsson M: 5-Fluorouracil signaling through a calcium-calmodulin-dependent pathway is required for p53 activation and apoptosis in colon carcinoma cells. Oncogene 2013, 32:4529-4538

41. Gestal C, Pallavicini A, Venier P, Novoa B, Figueras A: MgC1q, a novel C1q-domain-containing protein involved in the immune response of Mytilus galloprovincialis. Dev Comp Immunol 2010, 34:926-934.

42. Gray C, Loynes CA, Whyte MK, Crossman DC, Renshaw SA, Chico TJ: Simultaneous intravital imaging of macrophage and neutrophil behaviour during inflammation using a novel transgenic zebrafish. Thromb Haemost 2011, 105:811-819.

43. Machado C, Andrew DJ: D-Titin:a giant protein with dual roles in chromosomes and muscles. J Cell Biol 2000, 151:639-652.

44. Liu HL, Liu SF, Ge YJ, Liu J, Wang XY, Xie LP, Zhang RQ, Wang Z Identification and characterization of a biomineralization related gene PFMG1 highly expressed in the mantle of Pinctada fucata. Biochemistry 2007, 46:844-851.

45. Ni M, MacFarlane AW IV, Toft M, Lowell CA, Campbell KS, Hamerman JA: B-cell adaptor for PI3K (BCAP) negatively regulates Toll-like receptor signaling through activation of PI3K. Proc Natl Acad Sci U S A 2012, 109:267-272. 
46. Maruoka M, Suzuki J, Kawata S, Yoshida K, Hirao N, Sato S, Goff SP, Takeya T, Tani K, Shishido T: Identification of B cell adaptor for PI3-kinase (BCAP) as an Abl interactor 1-regulated substrate of Abl kinases. FEBS Lett 2005, 579:2986-2990.

47. Laurenzana EM, Chen T, Kannuswamy M, Sell BE, Strom SC, Li Y, Omiecinski CJ: The Orphan Nuclear Receptor, DAX-1, Functions as a Potent Co-repressor of the Constitutive Androstane Receptor (CAR, NR1I3). Mol Pharmacol 2012, 82:918-928.

48. Wang $\mathrm{N}$, Lee $\mathrm{YH}$, Lee J: Recombinant perlucin nucleates the growth of calcium carbonate crystals: molecular cloning and characterization of perlucin from disk abalone, Haliotis discus discus. Comp Biochem Physiol B Biochem Mol Biol 2008, 149:354-361.

49. Parcellier A, Gurbuxani S, Schmitt E, Solary E, Garrido C: Heat shock proteins, cellular chaperones that modulate mitochondrial cell death pathways. Biochem Biophys Res Commun 2003, 304:505-512.

50. Shelly M, Mosesson Y, Citri A, Lavi S, Zwang Y, Melamed-Book N, Aroeti B, Yarden Y: Polar expression of ErbB-2/HER2 in epithelia. Bimodal regulation by Lin-7. Dev Cell 2003, 5:475-486.

51. Irie M, Hata Y, Deguchi M, Ide N, Hirao K, Yao I, Nishioka H, Takai Y: Isolation and characterization of mammalian homologues of Caenorhabditis elegans lin-7: localization at cell-cell junctions. Oncogene 1999, 18:2811-2817.

52. Oettgen P, Kas K, Dube A, Gu X, Grall F, Thamrongsak U, Akbarali Y, Finger E, Boltax J, Endress G, Munger K, Kunsch C, Libermann TA: Characterization of ESE-2, a novel ESE-1-related Ets transcription factor that is restricted to glandular epithelium and differentiated keratinocytes. J Biol Chem 1999, 274:29439-29452.

53. Leotoing L, Chereau F, Baron S, Hube F, Valencia HJ, Bordereaux D, Demmers JA, Strouboulis J, Baud V: A20-binding inhibitor of nuclear factor-kappaB (NF-kappaB)-2 (ABIN-2) is an activator of inhibitor of NF-kappaB (IkappaB) kinase alpha (IKKalpha)-mediated NF-kappaB transcriptional activity. J Biol Chem 2011, 286:32277-32288.

54. Tornatore L, Thotakura AK, Bennett J, Moretti M, Franzoso G: The nuclear factor kappa B signaling pathway: integrating metabolism with inflammation. Trends Cell Biol 2012, 22:557-566.

55. Altschul SF, Gish W, Miller W, Myers EW, Lipman DJ: Basic local alignment search tool. J Mol Biol 1990, 215:403-410.

56. Barrett T, Troup DB, Wilhite SE, Ledoux P, Evangelista C, Kim IF, Tomashevsky M, Marshall KA, Phillippy KH, Sherman PM, Muertter RN, Holko M, Ayanbule O, Yefanov A, Soboleva A: NCBI GEO:archive for functional genomics data sets-10 years on. Nucleic Acids Res 2011, 39(Database issue):D1005-D1010.

57. Allam B, Paillard C, Ford SE: Pathogenicity of Vibrio tapetis, the etiological agent of brown ring disease in clams. Dis Aquat Organ 2002, 48:221-231.

58. Conesa A, Götz S, García-Gómez JM, Terol J, Talón M, Robles M: Blast2GO, a universal tool for annotation, visualization and analysis in functional genomics research. Bioinformatics 2005, 21:3674-3676.

59. Ashburner M, Ball CA, Blake JA, Botstein D, Butler H, Cherry JM, Davis AP, Dolinski K, Dwight SS, Eppig JT, Harris MA, Hill DP, Issel-Tarver L, Kasarskis A, Lewis S, Matese JC, Richardson JE, Ringwald M, Rubin GM, Sherlock G: Gene ontology, tool for the unification of biology. The Gene Ontology Consortium. Nat Genet 2000, 25:25-29.

60. Rozen S, Skaletsky HJ: Primer3 on the WWW for general users and for biologist programmers. Methods Mol Biol 2000, 132:365-386.

61. Pfaffl MW: A new mathematical model for relative quantification in real-time RT-PCR. Nucleic Acids Res 2001, 29:e45.

doi:10.1186/1471-2164-15-267

Cite this article as: Moreira et al:: Gene expression profile analysis of Manila clam (Ruditapes philippinarum) hemocytes after a Vibrio alginolyticus challenge using an immune-enriched oligo-microarray. BMC Genomics 2014 15:267.

\section{Submit your next manuscript to BioMed Central and take full advantage of:}

- Convenient online submission

- Thorough peer review

- No space constraints or color figure charges

- Immediate publication on acceptance

- Inclusion in PubMed, CAS, Scopus and Google Scholar

- Research which is freely available for redistribution

Submit your manuscript at www.biomedcentral.com/submit 